\title{
Meningkatkan Prestasi Belajar IPS Materi Kenampakan Alam Dan Gejala Sosial Negara-Negara Tetangga Dengan Model Pembelajaran Cooperative Learning Siswa Kelas VI Semester I SDN Bile Penanggak Kec. Janapria Tahun Pelajaran 2017/2018
}

\author{
Kartini \\ Guru Kelas SDN Bile Penanggak Kec. Janapria Kab. Lombok Tengah
}

\begin{abstract}
Abstrak. Berdasarkan hasil observasi dan data di SDN Bile penanggak, khususnya Kelas VI terdapat permasalahan yang dihadapi oleh siswa yaitu kurangnya motivasi dari diri siswa dalam mengikuti proses belajar mengajar mata pelajaran IPS, pernyataan tersebut didasarkan pula pada hasil nilai ulangan harian siswa pada mata pelajaran IPS yang cukup rendah dan daya serap siswa secara klasikal masih dibawah Kriteria Ketuntasan Minimal (KKM) secara klasikal yaitu 48,15\%. Secara rinci dari 27 siswa Kelas VI Semester I SDN Bile Penanggak Kecamatan Janapria Kabupaten Lombok Tengah Tahun Pelajaran 2017/2018 yang terdiri dari 12 siswa laki-laki dan 15 siswa perempuan,yang mendapat nilai $80-100$ adalah 2 siswa (7,41\%), yang mendapat nilai 70-79 sebanyak 11 siswa (40,74\%), yang mendapat nilai 60-69 sebanyak 3 siswa $(11,11 \%)$, yang mendapat nilai 40-59 sebanyak 11 siswa (40,74\%). Fakta ini menunjukkan bahwa siswa Kelas VI SDN Bile Penanggak belum mencapai prosentase ketuntasan belajar secara klasikal yaitu $80 \%$ sesuai dengan KKM yang telah ditetapkan. Disamping itu pengajar menyadari bahwa Model Pembelajaran pembelajaran yang dilakukan masih bersifat abstrak karena dalam memberikan penjelasan dilakukan secara singkat dan hanya mengunakan satu buku sumber. Berdasarkan hasil diskusi antara pengajar dan teman sejawat dan refleksi terhadap masalah tersebut disepakati bahwa pemecahan masalah akan dilakukan dengan menggunakan menggunakan Model Pembelajaran Cooperative Learning. Penelitian ini menggunakan rancangan penelitian tindakan kelas yang terdiri dari dua siklus. Pada masing-masing siklus dilakukan tahap perencanaan, pelaksanaan tindakan, pengamatan, dan refleksi. Subyek penelitian menggunakan siswa Kelas VI Sekolah Dasar Negeri Bile Penanggak Hasil penelitian dengan menggunakan Model Pembelajaran Cooperative Learning dapat melibatkan siswa secara aktif dalam pembelajaran, siswa dapat belajar mengajukan pertanyaan, mengembangkan pendapat, menghargai pendapat teman, dan belajar bekerjasama dengan teman, hal ini akan berpengaruh terhadap hasil belajar siswa menjadi lebih baik.
\end{abstract}

\section{Kata Kunci : Meningkatkan Prestasi Belajar,Model Pembelajaran Cooperative Learning IPS}

\section{PENDAHULUAN}

\section{Latar Belakang}

Dalam proses belajar mengajar guru menjadi pemeran utama dalam menciptakan situasi Cooperative Learning yang edukatif, yakni interaksi antara guru dengan siswa, siswa dengan siswa dan denga sumber pembelajaran dalam menunjang tercapainya tujuan belajar. Untuk terwujudnya proses belajar mengajar seperti itu sudah tentu menuntut upaya guru untuk mengaktualisasikan kompetensinya secara professional, utamanya aspek metodologis. IPS sebagai salah satu bidang studi yang memiliki tujuan membekali siswa untuk mengembangkan penalarannya disamping aspek nilai dan moral, banyak memuat materi social bersifat hapalan sehingga pengetahuan dan informasi yang diterima siswa sebatas produk hapalan. Sifat pelajaran IPS tersebut membawa konsekuensi terhadap proses belajar mengajar yang didominasi oleh pendekatan ekspositoris, terutama guru menggunakan Model Pembelajaran ceramah sedangkan siswa kurang terlibat atau cenderung pasif.

Dalam Model Pembelajaran ceramah terjadi dialog imperaktif. Padahal, dalam proses belajar mengajar keterlibatan siswa harus secara totalitas, artinya melibatkan pikiran, penglihatan, pendengaran, dan psikomoto (keterampilan, salah satunya 
sambil menulis). Jadi, dalam proses belajar mengajar, seorang guru harus mengajak siswa untuk mendengarkan, menyajikan media yang dapat dilihat, memberi kesempatan untuk menulis dan mengajukan pertanyaan atau tanggpan sehinga terjadi dialog kreatif yang menunjukkan proses belajar mengajar yang Cooperative Learning. Situasi belajar seperti ini dapat tercipta melalui penggunaan pendekatan partiestoris.

Proses belajar mengajar mempunyai makna dan pengertian yang lebih luas dari pada pengertian mengajar, karena didalamnya tersirat satu kesatuan kegiatan yang tidakterpisahkan antara siswa yang belajar dna guru yang mengajar, yang terjalin dalam bentuk interaksi edukatif. Peran guru dalam pembelajarn IPS mempunyai hubungan erat dengan cara mengaktifkan siswa dalam belajar, terutama dalam proses pengembangan keterampilannya. Pengembangan keterampilan yang harus dimiliki siswa adalah keterampilan berfikir, keterampilan social dan keterampilan praktis. Keterampilan berfikir dikembangkan untuk melatih siswa berfikir logis dan sistematis melalui proses belajar mengajar dengan model pengembangan berfikir kritis, keterampilan social dan praktis melalui model dialog kreatif.Ketiga keterampilan tersebut dapat dikembangkan dalam situasi belajar mengajar yang Cooperative Learning antara guru dengan siswa dan siswa dengan siswa.

Permasalahan yang muncul di sekolah saat melaksanakan pembelajaran siswa dalam bidang IPS adalah kurangnya motivasi dari diri siswa dalam mengikuti proses belajar mengajar. Mereka kurang serius dalam memfokuskan diri mengikuti materi pembelajaran IPS.Hal ini muncul karena dalam pelaksanaan belajar mengajar guru lebih sering menggunakan buku sebagai sumber belajar, dimana guru hanya menggunakan Model Pembelajaran ceramah saja dalam menjelaskan materi pembelajaran IPS.Tidak adanya media peraga atau contoh gambar yang merupakan sarana pengetahuan nyata bagi siswa.

Berdasarkan hasil observasi dan data di SDN Bile Penanggak, khususnya Kelas VI terdapat permasalahan yang dihadapi oleh siswa yaitu kurangnya motivasi dari diri siswa dalam mengikuti proses belajar mengajar mata pelajaran IPS, pernyataan tersebut didasarkan pula pada hasil nilai ulangan harian siswa pada mata pelajaran IPS yang cukup rendah dan daya serap siswa secara klasikal masih dibawah Kriteria Ketuntasan Minimal (KKM) secara klasikal yaitu 48,15\%. Secara rinci dari 27 siswa Kelas VI Semester I SDN Bile Penanggak Kecamatan Janapria Kabupaten Lombok Tengah Tahun Pelajaran 2017/2018 yang terdiri dari 12 siswa laki-laki dan 15 siswa perempuan,yang mendapat nilai 80-100 adalah 2 siswa $(7,41 \%)$, yang mendapat nilai $70-79$ sebanyak 11 siswa $(40,74 \%)$, yang mendapat nilai 60 69 sebanyak 3 siswa $(11,11 \%)$, yang mendapat nilai 40-59 sebanyak 11 siswa $(40,74 \%)$. Fakta ini menunjukkan bahwa siswa Kelas VI SDN Bile Penanggak belum mencapai prosentase ketuntasan belajar secara klasikal yaitu $80 \%$ sesuai dengan KKM yang telah ditetapkan.

Setelah kegiatan pembelajaran selesai peneliti mengadakan diskusi teman sejawat, hasil diskusi dengan teman sejawat ditemukan beberapa masalah yang terjadi dalam proses belajar mengajar, yaitu:

1. Kurangnya interaksi antara guru dan siswa.

2. Penguasaan guru tentang Model Pembelajaran pengajaran masih berada dibawah standar.

3. Siswa cenderung pasif dan kurangnya motivasi siswa.

4. Model Pembelajaran yang digunakan dalam mengajar hanya ceramah.

5. Siswa cenderung menghafal bukan memahami materi pelajaran.

\section{Rumusan Masalah}

Berdasarkan uraian di atas, maka rumusan masalah dalam penelitian ini adalah: "Bagaimanakah Meningkatkan Prestasi Belajar IPS Kenampakan alam dan Gejala Sosial Negara-Negara Tetangga dengan Model Pembelajaran Cooperative Learning siswa Kelas VI Semester I SDN Bile Penanggak Kecamatan Janapria Tahun pelajaran 2017/2018?”.

\section{Tujuan Penelitian}


Tujuan Penelitian ini adalah untuk mengetahui Bagaimanakah Meningkatkan Prestasi Belajar IPS Kenampakan alam dan Gejala Sosial Negara-Negara Tetangga dengan Model Pembelajaran Cooperative Learning siswa Kelas VI Semester I SDN Bile Penanggak Kecamatan Janapria Tahun pelajaran 2017/2018.

\section{Manfaat Penelitian}

Tindakan yang diberikan dalam dua siklus dapat bermanfaat bagi siswa untuk memberikan latihan/pengalaman untuk menyelesaikan masalah dan meningkatkan prestasi belajar siswa dengan harapan hasil PTK dapat bermanfaat bagi guru lain yang memiliki masalah yang sama/serupa sebagai input atau msukan untuk melakukan pemecahan masalah kelas di sekolah lain dalam rangka meningkatkan kualitas proses dan hasil pembelajaran IPS dengan menggunakan model pembelajaran

Cooperative Learning.

\section{LANDASAN TEORI DAN KAJIAN PUSTAKA}

\section{Model Pembelajaran Cooperative Learning (Pembelajaran Kooperatif)}

Pembelajaran Kooperatif adalah terjemahan dari Cooperative Learning. Menurut Sund "Cooperative Learning adalah proses mental dimana siswa mampu mengasimilasikan sesuatu konsep atau prinsip". Proses mental tersebut ialah mengamati, mencerna, mengerti, mengolonggolongkan, membuat dugaan, menjelaskan, mengukur, membuat kesimpulan dan sebagainya (Roestiyah, 2001:20).

Sedangkan menurut Jerome Bruner "Pembelajaran Kooperatif adalah suatu proses, suatu jalan/cara dalam mendekati permasalahan bukannya suatu produk atau item pengetahuan tertentu". Dengan demikian di dalam pandangan Bruner, belajar dengan Pembelajaran Kooperatif adalah belajar untuk menemukan, dimana seorang siswa dihadapkan dengan suatu masalah atau situasi yang tampaknya ganjil sehingga siswa dapat mencari jalan pemecahan (Markaban, 2006:9).

Model Pembelajaran Kooperatif terbimbing menempatkan guru sebagai fasilitator. Guru membimbing siswa dimana ia diperlukan. Dalam model ini, siswa didorong untuk berpikir sendiri, menganalisis sendiri sehingga dapat "menemukan" prinsip umum berdasarkan bahan atau data yang telah disediakan guru (PPPG, 2004:4)

Model Pembelajaran Kooperatif terbimbing atau terpimpin adalah model pembelajaran Pembelajaran Kooperatif yang dalam pelaksanaanya dilakukan oleh siswa berdasarkan petunjuk-petunjuk guru. Petunjuk diberikan pada umumnya berbentuk pertanyaan membimbing (Ali, 2004:87).

Dari pendapat diatas dapat disimpulkan bahwa model Pembelajaran Kooperatif terbimbing adalah model pembelajaran yang dimana siswa berpikir sendiri sehingga dapat "menemukan" prinsip umum yang diinginkan dengan bimbingan dan petunjuk dari guru berupa pertanyaanpertanyaan yang mengarahkan. ciri utama belajar menemukan yaitu: (1) mengeksplorasi dan memecahkan masalah untuk menciptakan, menggabungkan dan menggeneralisasi pengetahuan; (2) berpusat pada siswa; (3) kegiatan untuk menggabungkan pengetahuan baru dan pengetahuan yang sudah ada.

\section{Kelebihan dan kekurangan Model Pembelajaran (Cooperative Learning) Pembelajaran Kooperatif}

Memperhatikan Model Pembelajaran Kooperatif Terbimbing tersebut diatas dapat disampaikan kelebihan dan kekurangan yang dimilikinya, Kelebihan Model Pembelajaran Kooperatif Terbimbing adalah sebagai berikut (Marzano; 1992): (a) Siswa dapat berpartisipasi aktif dalam pembelajaran yang disajikan, (b) Menumbuhkan sekaligus menanamkan sikap inquiry (mencaritemukan), (c) Mendukung kemampuan problem solving siswa, (d) Memberikan wahana interaksi antar siswa, maupun siswa dengan guru, dengan demikian siswa juga terlatih untuk menggunakan bahasa Indonesia yang baik dan, (e) Materi yang dipelajari dapat mencapai tingkat kemampuan yang tinggi dan lebih lama membekas karena siswa dilibatkan dalam proses menemukanya.

Kekurangan Model Pembelajaran Kooperatif Terbimbing adalah sebagai berikut : (a) Untuk materi tertentu, waktu yang tersita lebih lama, 
(b) Tidak semua siswa dapat mengikuti pelajaran dengan cara ini. Di lapangan, beberapa siswa masih terbiasa dan mudah mengerti dengan model ceramah, (c) Tidak semua topik cocok disampaikan dengan model ini. Umumnya topik-topik yang berhubungan dengan prinsip dapat dikembangkan dengan Model Pembelajaran Kooperatif Terbimbing.

\section{Pengertian Prestasi Balajar}

Prestasi Belajar atau Hasil Belajar (Achievement) yang merupakan realisasi atau perkara dari kecakapan-kecakapan potensial atau kapasitas yang di miliki seseorang. Berikut merupakan beberapa definisi tantang prestasi belajar menurut beberapa ahli, yaitu:

1. Sumadi Suryabrata, Prestasi Belajar adalah nilai sebagai rumusan yang diberikan guru bidang studi mengenai kemajuan atau prestasi belajar selama masa tertentu. (Sumadi Suryabrata, 1998)

2. Siti Pratini, Prestasi Belajar adalah suatu hasil yang dicapai seseorang dalam melakukan kegiatan belajar. (Siti Pratini, 2005)

3. Kamus Bahasa Indonesia yang dinamakan Prestasi adalah hasil yang telah dicapai, dilakukan, dikerjakan dan sebagainya.

4. Bukhari M.Ed, Prestasi dapat kita artikan sebagai hasil yang telah dicapai atau hasil yang sebenarnya dicapai. (Bukhari M, 1983)

5. WS.

Winkel, Prestasi belajar merupakan $h$ asil

belajar yang ditampakkan oleh siswa berdasarkan kemampuan internal yang diperoleh sesuai dengan tujuan instruksional. (Winkel WS, 1989)

Berdasarkan pendapat para ahli tentang Pengertian Prestasi Belajar, maka dapat disimpulkan bahwa Prestasi Belajar adalah hasil yang dicapai atau ditunjukkan oleh peserta didik sebagai hasil belajarnya yang diperoleh melalui pengalaman dan latihan. Hal ini biasanya berupa angka-angka, huruf, serta tindakan yang dicapai masingmasing peserta didik dalam waktu tertentu.

Dari berbagai pengertian tentang prestasi belajar di atas dapat diambil kesimpulan bahwa sebenarnya Prestasi Belajar peserta didik tidak selamanya merupakan gambaran dari kemampuan yang sebenarnya. Dengan demikian Prestasi Belajar di sekolah tidak selalu di wujudkan dengan kecakapan-kecakapan, namun kecakapan itu hanya merupakan sabagian dari unsur pertumbuhan, dan pembentukan dari suatu prestasi belajar.

Kemampuan-kamampuan peserta didik dalam proses belajar mengajar oleh Benyamin Bloom yang dikutip oleh Nana Sudjana, 2009 mengklasifikasikan secara garis besar menjadi tiga ranah sebagai berikut: (1) Ranah Kognitif, (2) Ranah Afektif, (3) Ranah Psikomotorik

Ketiga ranah tersebut menjadi objek penilaian hasil belajar. Diantara ketiga ranah tersebut, ranah kognitiflah yang paling banyak dinilai oleh para pendidik di sekolah karena berkaitan dengan kemampuan peserta didik dalam menguasi isi bahan pengajaran.

\section{METODHE PENELITIAN}

\section{Setting Penelitian}

Penelitian ini di laksanakan di SD Negeri Bile Penanggak Kecamatan Janapria Kabupaten Lombok Tengah Tahun Pelajaran 2017/2018. pada Hari Kamis,10 Oktober 2017 (Siklus I) dan Hari Kamis, 17 Oktober 2017 (Siklus II).

Mata Pelajaran yang diteliti adalah Ilmu Pengetahuan Sosial dengan materi Kenampakan Alam Kelas VI Semester I dengan jumlah siswa 27 orang, terdiri dari 12 siswa laki-laki dan 15 siswa perempuan. Karakteristik siswa SDN Bile Penanggak, keadaan ekonomi rata-rata menengah kebawah karena $75 \%$ wali murid berprofesi sebagai Buruh Tani, Pendidikan wali murid rata-rata tamatan Sekolah Dasar, bahkan masih banyak siswa yang ikut bekerja membantu orang tua mencari napkah dan kecerdasan siswa sangat heterogen.

\section{Prosedur Penelitian}

Kegiatan penelitian ditempuh melalui prosedur yang ditentukan, yaitu melalui empat tahap, yaitu perencanaan pembelajaran, pelaksanaan pembelajaran, observasi dan pencatatan pembelajaran, dan analisis serta refleksi pembelajaran 
Perencanaan tindakan penelitian dilakukan berdasarkan hasil orientasi dan identifikasi masalah pengajaran. Kegiatankegiatan yang dilakukan dalam tahap ini adalah : (1) Menelaah kurikulum SD Kelas VI Mata pelajaran IPS (2) menyusun Rencana Pelaksanaan Pembelajara n IPS (3) menyusun lembar observasi proses pelaksanaan pembelajaran (4) Membuat LKS (5) Menyusun alat evaluasi.

\section{Pelaksanaan Tindakan Penelitian}

Empat tahap kegiatan yang dilakukan pada setiap siklus tindakan pembelajaran adalah seperti di bawah ini.

\section{Perencanaan Tindakan}

Kegiatan perencanaan tindakan

1) Membuat

Rencana Pelaksanaan Pembelajaran (RPP) berdasarkan prioritas masalah yaitu penggunaan model pembelajaran Cooperative Learning (Pembelajaran Kooperatif) pada pembelajaran IPS tentang Materi Kenampakan Alam, 2) Mempersiapkan alat atau media pembelajaran yang akan digunakan yaitu model Pembelajaran Cooperative Learning (Pembelajaran Kooperatif) untuk setiap kelompok, 3) Membicarakan prosedur pelaksanaan pengajaran IPS tentang Materi Kenampakan Alam menggunakan model Pembelajaran Cooperative Learning (Pembelajaran Kooperatif) 4) Menyusun instrumeninstrumen yang akan digunakan.

Pelaksanaan Pembelajaran

Dalam pelaksanaan pembelajaran, peneliti melaksanakan pembelajaran tentang penggunaan model Pembelajaran Cooperative Learning (Pembelajaran Kooperatif) dan mencatat berbagai temuan selama kegiatan pembelajaran sebagai bahan refleksi pada pelaksanaan pada siklus 1 khususnya yang berhubungan dengan fokus penelitian.

\section{Observasi Pelaksanaan Penelitian}

Peneliti dengan berkolaborasi dengan teman sejawat yaitu Sri Handayani, S.Pd, melakukan analisis dan refleksi terhadap pelaksanaan pembelajaran, untuk keperluan analisis dilakukan pemeriksaan lembar pengamatan dan catatan-catatan tentang data yang terkumpul. Hasil observasi sebagai temuan dijadikan sebagai rekomendasi hasil penelitian dan rencana tindakan selanjutnya.

\section{Analisis dan Refleksi Pembelajaran}

Peneliti bersama-sama dengan rekan sejawat melakukan analisis dan refleksi data yang terkumpul selama kegiatan pembelajaran. Berdasarkan hasil analisis dan refleksi dijadikan bahan untuk melakukan tindakan penelitian.

\section{Pengumpulan Data \\ Teknik Pengumpulan Data}

Teknik pengumpulan data yang digunakan dalam penelitian ini terdiri dari 2 teknik, yaitu teknik observasi dan teknik tes.

\section{Teknik Observasi}

Observasi dilakukan selama kegiatan pembelajaran berlangsung dengan menggunakan lembar observasi yang dibuat untuk digunakan sebagai perangkat pengumpul data. Adapun hal-hal yang diobservasi antara lain: 1) Observasi terhadap rencana pembelajaran, 2) Observasi terhadap proses pembelajaran, 3) Observasi terhadap hasil yang diperoleh siswa setelah dilakukan tindakan.

\section{Teknik Tes}

Teknik tes dilakukan pada akhir kegiatan pembelajaran dengan menggunakan lembar soal.

\section{Alat Pengumpulan Data}

Alat pengumpulan data yang digunakan dalam penelitian ini adalah: (a) Butir Soal tes sebanyak 5 nomor, 9b) Lembar Observasi, yaitu: 1) Observasi terhadap rencana pembelajaran, 2) Observasi terhadap proses pembelajaran, 3) Observasi terhadap hasil yang diperoleh siswa setelah dilakukan tindakan.

\section{Analisa Data}

Teknik analisis data yang digunakan ada yang bersifat kuantitatif dan kualitatif. Data yang diperoleh dikatagorikan dan diklasifikasikan berdasarkan analisis kaitan logisnya, kemudian disajikan secara aktual dan sistematis dalam keseluruhan permasalahan dan kegiatan penelitian.Selanjutnya untuk menganalisis data, hasil tindakan yang dilakukan penulis disajikan secara bertahap sesuai urutan siklus 
yang telah dilaksanakan, adapun prosedur pengolahan data adalah sebagai berikut :

\section{a. Seleksi Data}

Data yang telah terkumpul dari hasil observasi selama kegiatan penelitian maka diadakan penyeleksian data yang ada kaitannya dengan tujuan penelitian.

\section{b. Klasifikasi Data}

Data yang terkumpul berdasarkan penyeleksian, diklasifikasikan berdasarkan urutan logis untuk disajikan secara sistematis berdasarkan urutan siklus.

\section{c. Prosentase Data}

Tahap akhir dari teknik analisis data, dilakukan prosentase data bagi data yang telah terkumpul beradasarkan klasifikasi.

\section{Indikator Kinerja}

1. Secara individu : Keberhasilan setiap individu apabila hasil tes formatifnya mencapai angka 70 sesuai dengan KKM yang ditetapkan.

2. Secara klasikal apabila siswa yang tuntas belajar mencapai sebesar $80 \%$ dari seluruh siswa yang ada.

\section{HASIL PENELITIAN DAN \\ PEMBAHASAN \\ Hasil Penelitian \\ Kondisi Awal}

Berdasarkan data Tahun Pelajaran

2017/2018, jumlah siswa SDN Bile Penanggak 148 orang siswa terdiri dari 69 laki-laki dan 79 perempuan, keadaan ekonomi wali murid rata-rata menengah kebawah karena $75 \%$ wali murid berprofesi sebagai Buruh Tani, Pendidikan wali murid rata-rata tamatan Sekolah Dasar, bahkan masih banyak siswa yang ikut bekerja membantu orang tua mencari napkah dan kecerdasan siswa sangat heterogen. Siswa Kelas VI SD Negeri Bile Penanggak pada Semester I terdiri dari 27 siswa yaitu 12 laki-laki dan 15 Perempuan. Aktivitas siswa dalam pembelajaran Ilmu Pengetahuan Sosial, siswa kurang antusias dalam menghadapi pelajaran,terbukti dari hasil pra siklus hanya 13 siswa $(48,15 \%)$ yang memperoleh nilai $\geq$ 70 dimana angka KKM yang ditetapkan 70 ,sedangkan 14 siswa $(51,85 \%)$ memperoleh nilai $\leq 69$, dengan nilai rata rata
58,52 , nilai terendah 40 dan nilai tertinggi 80 , hal ini salah satu penyebabnya adalah guru tidak menggunakan Model pembelajaran yang tepat.

Siklus I

Tindakan pembelajaran yang akan dilaksanakan adalah dengan menggunakan Model Pembelajaran Cooperative Learning (Pembelajaran Kooperatif), siswa dalam kegiatan belajar akan dikelompokkan kelompok, setiap kelompok terdiri dari 5 dan 6 orang, dengan tujuan agar siswa dalam kelompok memperoleh kesempatan yang lebih banyak dalam melaksanakan kegiatan.

Perencanaan

Untuk menjaring data dalam penelitian, maka langkah selanjutnya membuat lembar observasi, antara lain : 1) Menyusun Rencana Pelaksanaan Pembelajaran (RPP), 2) Lembar observasi Rancangan Pelaksanaan Pembelajaran,

3) Lembar observasi Pelaksanaan Pembelajaran 4) Lembar observasi Kemampuan Siswa pada Materi Kenampakan Alam

Tindakan penelitian siklus I berdasarkan perencanaan tindakan penelitian yang telah ditetapkan dan hasilnya disusun berdasarkan katagori data dibawah ini :

\section{Pelaksanaan}

Proses pembelajaran pada Siklus I meliputi kegiatan guru dalam mengajar, dan siswa dalam belajar dapat dilihat pada tabel Dari tabel dapat kita lihat Siswa yang mendapat nilai di atasyang memperoleh nilai $\geq 70$ sebanyak 18 Siswa, atau 66,67\% sedangkan yang memperoleh nilai $\leq 69$ sebanyak 9 Siswa atau 33,33\% dari 27 Siswa dengan nilai rata rata 70 dengan nilai terendah 50 dan nilai tertinggi 80 .

\section{Refleksi}

Peneliti bersama-sama Observer melakukan analisis dan refleksi data yang terkutnpul selama kegiatan pembelajaran. Berdasarkan hasil analisis dan refleksi dijadikan bahan untuk melakukan tindakan penelitian Hasil refleksi dari siklus I merupakan rekomendasi untuk siklus II agar pembelajaran lebih baik dan sesuai dengan tujuan penelitian. Adapun kegiatan 
perencanaan untuk kegiatan pembelajaran siklus 2 antara lain merefisi dan melengkapi RencanaPelaksanaan pembelajaran (RPP) terutarna dalam Proses Belajar Mengajar.

\section{Siklus II}

\section{Perencanaan}

Untuk menjaring data dalam penelitian, maka langkah selanjutnya membuat lembar observasi, antara lain : 1) Menyusun Rencana Pelaksanaan Pembelajaran (RPP) yang telah disampurnakan, 2) Lembar observasi Rancangan Pelaksanaan Pembelajaran,

3) Lembar observasi Pelaksanaan Pembelajaran, 4) Lembar observasi Kemampuan Siswa pada Materi Kenampakan Alam. Tindakan penelitian siklus I berdasarkan perencanaan tindakan penelitian yang telah ditetapkan dan hasilnya disusun berdasarkan kriteria yang telah ditetapkanTindakan penelitian siklus 2 berdasarkan repleksi siklus 1, dan hasilnya disusun berdasarkan katagori data dibawah ini:

\section{Pelaksanaan}

Proses pembelajaran pada siklus 2 meliputi kegiatan guru dalam mengajar, dan siswa dalam belajar

\section{Observasi}

Berdasarkan data yang terkumpul dari hasil evaluasi yang dilaksanakan pada Siklus 2, masih ada beberapa siswa yang belum tuntas, Dari hasil analisa data dapat dijelaskan; Siswa yang mendapat nilai $\geq 70$ sebanyak 24 Siswa, atau 88,89\% sedangkan nilai $\leq 69$ sebanyak 3 Siswa atau $11,11 \%$ dari 27 Siswa,dengan nilai rata rata 76,48 , dengan nilai terendah 60 dan nilai tertinggi 90, ini disebabkan karena pemahaman siswa terhadap materi semakain meningkat.

Berdasarkan hasil penelitian pada Siklus 2 maka hasil refleksi selama kegiatan pada penelitian yang dimulai dari persiapan, pelaksanaan dan penilaian/Evaluasi dianggap sudah berhasil, hal ini berdasarkan tingkat kemampuan siswa yang cukup baik.

\section{KESIMPULAN DAN SARAN}

Pada pra Siklus jumlah siswa yang tidak tuntas dalam mengikuti pembelajaran 13 orang siswa. Setelah dilaksanakan perbaikan pembelajaran pada
Siklus 1 nampak sekali peningkatan hasil belajar siswa yaitu sebesar $66,67 \%$, atau 18 siswa, sudah tuntas dan 9 siswa masih belum tuntas. Pada siklus 2 mengalami peninkatan secara signifikan dimana siswa yang tuntas belajar sebesar $88,89 \%$ atau 23 orang siswa dan yang belum tuntas sebanyak 3 orang siswa atau $11,11 \%$. Berdasarkan uraian pembahasan dan hasil penelitian di atas mulai Siklus 1 sampai siklus 2 mengenai penggunaan model pembelajaran Cooperative Learning, dapat peneliti simpulkan bahwa: 1 . Dengan menggunakan pembelajaran Cooperative Learning, mampu meningkatkan prestasi belajar siswa Kelas VI SD Negeri Bile Penanggak pada materi kenampakan alam. 2. Melalui pembelajaran Cooperative Learning, siswa dapat lebih aktif dalam kegiatan belajar

Berdasarkan kesimpulan di atas serta hasil perbaikan dan pembelajaran, agar kegiatan belajar mengajar Ilmu Pengetahuan Sosial yang membahas mengenai "Kenampakan Alam" anak lebih aktif, kreatif dan memberikan hasil yang optimal bagi siswa. Maka ada beberapa saran yang dapat disampaikan sebagai berikut: 1 . Dalam kegiatan pembelajaran IPS sebaiknya guru menggunakan model pembelajaran Cooperative Learning, karena dengan model pembelajaran tersebut dapat meningkatkan prestasi belajar siswa. 2. Guru hendaknya menerapkan pembelajaran Cooperative Learning, karena dapat mengaktifkan siswa dalam pembelajaran.

\section{DAFTAR PUSTAKA}

Roestiyah. (2001). Strategi Belajar Mengajar. Jakarta: Rineka Cipta.

Markaban, (2006 ).Penelitian Tindakan Kelas. Jakarta: bumi Aksara.

Bell. 1978. 5. Teaching Mathematics: Developing as A Reflective Secondary Teacher

Budiningsih, Asri. (2005). Belajar dan Pembelajaran. Jakarta: PT. Rineka Cipta.

Syah. 2004. Psikologi Pendidikan dengan Pendekatan Baru. Bandung: PT Remaja

Taba dalam Affan..(1990).Generalisasi. Banguntapan Jogjakarta: 
Djamarah. (2002). Teori Motivasi, edisi 2 (ed2), Jakarta : PT. Bumi Aksara.

Voigt, R., 1994, Buku Pelajaran Teknologi Farmasi, diterjemahkan oleh: Soendani.

Slavin, Robert E., (1994). Science Instruction ... Rineka Cipta. .

Ratumanan. 2002.Analisis Data Kualitatif (Buku. Sumber Tentang Model Pembelajaran-Model Pembelajaran Baru). Jakarta: UIP. ...

Marzano. 1992.Pembelajaran Kooperatif. Yogyakarta : Pustaka Pelajar.

Depdiknas-Bapenas-Adicitakaryanusa, 2001. Fuad Ihsan. 2003. .... Mulyani Sumantri \& Johar Permana. 2001.

Dahrendorf, Ralf. 1998. ... S. 2000. Filsafat Ilmu Suatu Pengantar Populer. Jakarta: Pustaka Sinar Harapan

Sumadi Suryabrata. (1998). Psikologi Pendidikan. Jakarta: Raja Grafindo

Siti Pratini. (2005). Psikologi Pendidikan. Yogyakarta: Studing

Bukhari M. (1983). Teknik-Teknik Evaluasi Dalam Pendidikan. Bandung: Jemmars

Winkel WS. (1989). Psikologi Pengajaran. Jakarta: Gramedia 